China Perspectives

2020-1 | 2020

Sights and Sounds of the Cold War in Socialist China and Beyond

\title{
Cultural Imagining of the Cold War: An Introduction
}

\section{Lingchei Letty Chen}

\section{(2) OpenEdition}

\section{Journals}

Electronic version

URL: https://journals.openedition.org/chinaperspectives/9816

DOI: 10.4000/chinaperspectives.9816

ISSN: 1996-4617

\section{Publisher}

Centre d'étude français sur la Chine contemporaine

Printed version

Date of publication: 1 March 2020

Number of pages: 3-6

ISSN: 2070-3449

\section{Electronic reference}

Lingchei Letty Chen, "Cultural Imagining of the Cold War: An Introduction", China Perspectives [Online], 2020-1 | 2020, Online since 01 March 2020, connection on 02 July 2021. URL: http://

journals.openedition.org/chinaperspectives/9816; DOI: https://doi.org/10.4000/chinaperspectives 9816 


\title{
Cultural Imagining of the Cold War: An Introduction
}

\author{
LINGCHEI LETTY CHEN
}

$\mathrm{T}$ he year 1989 has been commonly accepted as the time when the Cold War officially ended, epitomised by the worldwide broadcasting of the fall of the Berlin Wall on November 9. Since then, political scientists and historians have provided the world with a wealth of knowledge of what went on during the Cold War: the intricate intertwining of proxy wars, espionage, diplomatic manoeuvring, and propaganda campaigns across the globe. The Cold War may have been declared a closed chapter of history, but much of the cultural play throughout those years and around the globe still requires scholarly exploration and examination. Existing scholarship on the Cold War privileges diplomatic, military, and political history due in large part to the type of primary sources on which scholars draw. This Cold War discourse has produced a historical perception of the second half of the twentieth century as a polarised world dominated by political and ideological bifurcation of the Capitalist Western bloc, led by the US-UK alliance, and the Communist Eastern bloc, led by the Soviet Union, with the newly established People's Republic of China (PRC) being one of the largest nation-members of this coalition. But the world in reality did not experience the Cold War in such a neatly divided fashion. As Heonik Kwon aptly points out in The Other Cold War, to the European and North American nations, the Cold War era meant "a 'long peace'," whereas "for many new post-colonial nations elsewhere, the onset of the Cold War meant entering an epoch of 'unbridled reality' characterized by vicious civil wars and other exceptional forms of political violence" (Kwon 2010: 6). While Kwon's main argument centres on challenging the general consensus of the end of the Cold War as having a definitive historical marker, how the Cold War was experienced by ordinary people in their everyday lives in varying societies across the globe also deserves to be investigated. As our understanding of the Cold War expands and becomes more nuanced, so will our perception of the socialist China led by Mao Zedong and the Chinese Communist Party.

Mao's entire reign (1949-1976) spanned the Cold War years. Mao came into power after he led the Communist Party, with the support of the Soviet Union, to win the civil war against the ruling Nationalist Party (Kuomintang). Psychologically, the defeat of the US-backed Nationalist Party created an imminent sense of threat to the West. As Martin Walker makes plain, the crisis of morale over the loss of China to the Communists was one of the worst moments in the early years of the Cold War (Walker 1993: 67). The defeated Nationalist Party retreated to Taiwan, with the protection of Washington. The Chinese civil war escalated the tension between the US and the USSR, and effectively launched the Cold War in East Asia.

During its early years, the new China leaned heavily on the Soviet Union for international strategic advice and domestic technological, industrial, and economic support. As the CCP began rebuilding war-torn China, Mao's resolve to continue the socialist-communist revolution never wavered. We tend to characterise Mao's reign as a series of political campaigns, primarily Land Reform (1947-50), the Anti-Rightist Movement (1957), the Great Leap Forward (1958-62) that led to the Great Famine, and the Cultural Revolution (1966-76). But such a conception is not enough to tell the full story of socialist China. For example, the solidarity between the PRC and the Soviet Union in the early 1950s began to show signs of trouble in the latter part of the decade, culminated in a brutal border war in 1969 that irrevocably damaged the Sino-Soviet alliance. Three years after the border conflicts, China and the US began the so-called Ping-Pong diplomacy. Henry Kissinger secretly met with Prime Minster Zhou Enlai in 1971 and paved the way for Richard Nixon to visit China and meet with Mao. Essentially, the meeting of these two leaders from the opposing sides of the Cold War and the formalisation of diplomatic relations between the US and the PRC saw the beginning of the end of the Cold War in East Asia. As Chen Jian points out, "With Mao's death and the end of his revolution as well as Deng's altering the basic courses of China's external policies, the Cold War in Asia - as far as some of its fundamental features are concerned - virtually came to an end in the late 1970s, almost one decade before the conclusion of the global Cold War" (Chen 2001: 278).

Our understanding of China's socialism-communism thus needs to be squarely situated within the Cold War context, particularly the culturalpropagandic actions and interactions across national borders. In this cultural Cold War context, Maoist socialism-communism may not be simply understood as anti-capitalism. The rise of communism during the first three decades of the twentieth century in Republican China represented an effort to oppose Western and Japanese imperialisms, an answer to China's urgent need for modernisation, and a struggle to fight social injustice persisting from the old feudalistic days. Chinese communism was therefore not merely an ideological opposition to capitalist systems. With the founding of the People's Republic of China, the new socialist government continued on the path of modernisation through such campaigns as Land Reform and the Great Leap Forward guided by communist doctrines. Across the Taiwan Strait, on the other hand, the defeated Republican government, headed by Chiang Kai-shek, launched a series of anti-communist campaigns in the 1950s and continued through the 1960s. However, belying these campaigns - best exemplified by anti-communist literature - were Chiang Kai-shek's struggle for political survival through securing an alliance with the US, the collective trauma and longing of a generation of displaced people through the loss of the Chinese homeland, and the brutal suppression of the native Taiwanese by the Nationalist government. In other words, communism was not the actual target of these anti-communist campaigns but a veneer that masked political calculation, dislocation, and oppression.

This shift of perspective on how the Cold War played out in the East Asian 
region leads to questions of sources for historical investigations. Conventional sources such as files of central officials, military commanders, and foreign ministries reveal more about the top leaders than ordinary people, about the state and state agents than about grassroots society, about official intent than about the actual social consequences and popular reactions. Take the following academic monographs as examples of this perspective shift. Grace Ai-ling Chou's Confucianism, Colonialism and the Cold War (2011) uses New Asia College (now the Chinese University of Hong Kong) as her primary example to examine post-1949 Hong Kong's ambivalent and complex position as Chinese intellectual refugees from the mainland, the British colonial government, and American NGOs worked towards building a higher-education institution to be an ideologically neutral ground amidst the partisan Cold War politics. Xiaojue Wang's Modernity with a Cold War Face: Reimagining the Nation in Chinese Literature across the 1949 Divide (2013) situates the discourse of Chinese literary modernity in the Cold War context to illustrate how Chinese and Chinese diasporic writers grappled with a new socio-political and cultural reality beset by the establishment of the PRC on the mainland and the reinstated Republic of China on Taiwan, while many intellectuals sought safe haven in the Crown Colony of Hong Kong. Masuda Hajimu draws his archival materials from Taiwan, the PRC, Japan, India, Singapore, the Philippines and major Western countries, and argues in Cold War Crucible: The Korean Conflict and the Postwar World (2015) that it was individual people, not the governments, who in fact played a vital role in generating the fear and suppression of opposing political positions that were hallmarks of the Cold War. Emily Wilcox, one of the contributors in this special issue, in Revolutionary Bodies: Chinese Dance and the Socialist Legacy (2018), tracks the history of Chinese concert dance and demonstrates that socialist China's national dance drew inspiration from more than just the Soviet Union's revolutionary ballets, and that the circulation of PRC socialist dance went beyond the Eastern bloc to many Chinese diasporic communities around the globe.

By examining a wide range of cultural products such as film, folk dance, ballet, pamphlets and posters, and visual and audio technologies such as CinemaScope, microscopes, and film-dubbing techniques, this special issue also switches the focus of investigation from elite politics to popular cultural productions and practices. As Roland Vegso argues in The Naked Communist: Cold War Modernism and the Politics of Popular Culture, the warfare that was fought in the Cold War was not the conventional military one but instead, "culture itself became a political weapon" (Vegso 2013: 40). What the following five essays will demonstrate is precisely how culture (as both abstract ideas and concrete forms), science, and technology were utilised as instruments in one-upping the enemy, both real and imagined, in more ways than one, as cultural products and materials such as propaganda posters and pamphlets, films and documentaries, folk dances and classical ballets were propagated within as well as beyond national boundaries. The Cold War, after all, was a war of perception.

Taking socialist China as their common point of departure and in dialogue with scholarly works such as Ban Wang's "The Cold War, Imperial Aesthetics, and Area Studies" (Wang 2002: 45-65) and Petrus Liu's "Cold War Aesthetics in East Asia" (Liu 2019: 52-76), the five contributors consider the ways in which the Cold War was presented and understood in cinemas and theatres, both abroad and at home, among translators, filmmakers, and dubbing artists, on street corners and in residential neighbourhoods and school rooms. In these mundane places, ordinary people sought to make sense of the war, and they reworked elements of the official message and gave it a different logic and a new meaning. By exploring the connection between the official and grassroots levels, between political rhetoric and cultural representations, this special issue uncovers the social and cultural meaning of the Cold War and investigates how the global political climate affected socialist China's cultural import and export and how such activities shaped Chinese citizens' world views. The contributors in this special issue are interested in understanding how the Cold War was experienced in the quotidian and the manifestations of such experiences, how local cultures were thus turned into a site of ideological competition and power struggle, and how various forms of cultural production and consumption created images of enemies and allies as well as a global imaginary of division and integration.

The binary worldview created by the Cold War was an ideological one propelled and strengthened by media technologies such as CinemaScope. As Ling Kang argues in his article, "CinemaScope's Chinese Journey: The Technological Modernisation and the Logistics of Perception of the Cold War," as early as the mid-1950s, the newly founded People's Republic of China devoted significant resources to building its first wide-screen, stereophonic system of CinemaScope, which debuted in 1957 and was unrivalled by any traditional cinematic setups. Armed with this state-of-theart mega cinema, China was able to engage in cultural warfare on its own terms, while boasting to the world of the new socialist China's technological achievement, now equal to that of the USSR. It is thus fair to assert, as Kang argues, that CinemaScope represented the PRC government's early global ambition in claiming technological advancement, declaring the triumphant result of China's modernisation project that began in late nineteenth century.

The extraordinary visual and sonic effects generated by the new technology of CinemaScope provided the Chinese audience with a brand new sensory experience so unprecedented and modern that it would have ordinary Chinese movie-goers believe that communism was the answer and solution to the Euro-American and Japanese imperialisms that had plagued China since the mid-eighteenth century. These former enemies were now joined together as the Capitalist bloc led by the United States. CinemaScope as an advanced media technological achievement thus carried a symbolic significance to the collective Chinese psyche that, as a powerful weapon, it could fight the "other" side and win the war. As articulated by Kang, "the development of CinemaScope was rooted in the Cold War cultural competition that linked art to power and turned the achievement of cinematic technology into the indicator of political supremacy" (see Kang's article in this issue). In a way, CinemaScope was the battlefield that could and did fight a proxy war for the Communist bloc in general and the PRC in particular.

The grandeur of CinemaScope found an interesting companion in the significantly much smaller and simpler microscope, as both share a similar importance in disseminating, through science and technology, propagandic messages of the enemy. The second article of this special issue, entitled "Bacterial Imagination: Seeing the Enemy in Early 1950s People's Republic of China," by Lu Liu, takes the PRC government's launch of the anti-germ campaign in the early 1950s, against the backdrop of the Korean War (19501953), as an example to argue that taking the Capitalist Bloc as an enemy required as much imagination as the germs that are invisible to the naked eye. Applying the phrase weisheng 衛生 to the PRC government's antigerm warfare campaign and returning the phrase's meaning, understood as "hygienic modernity," back to its literal translation as "guarding life," Liu draws a parallel between germs and enemies, hygiene and geopolitics. To guard one's health/life from the attack of germs took on a collective significance; or conversely, to guard the nation's health/life from the attack of enemies assumed an intimate dimension. Liu continues to demonstrate 
that with the magnifying power of the microscope, bacteria were discovered and shown to educate the public through science education films and exhibits in classrooms, street corners, as well as cinemas. Channelled through mass media, the conversion of specialised scientific knowledge to understandable and teachable materials brought the ideological Cold War down to the grassroots level. Propaganda, pedagogy, and hygiene were thus rolled into one mass campaign promoting the fight against the invisible enemy - germs and the capitalist bloc - both at home and abroad.

But for any campaign to be effective, its rhetoric needs to have emotional appeal. The microscopic images were used as metaphors to recast China's historical shame and trauma, such as having been labelled "the Sick Man of Asia," and Japan's bacteriological tests on Chinese people from 1932 to 1945 (see Liu's article in this issue). This storytelling through abjection, as Liu argues, created a strong dichotomous sense of "us vs them" and thereby contributed considerably to the new socialist China's national subject formation. On the individual level, however, Liu contends that the subject formation process is more complex and ambiguous. For example, the scientists were required to disavow their expert status, and acceptance of being a socialist subject had to take precedence. Their constant close contact with bacteria also put them uncomfortably on the side of the germs that were supposedly the enemy. The us-them dichotomy, in the case of the Chinese scientists, thus becomes more contentious and less clear-cut. As the anti-germ campaign gave way to the more long-term and larger mass mobilisation movement of the Patriotic Hygiene Campaign, scientists eventually lost their critical position in the campaign, and ordinary citizens took over as the campaign focus now shifted to eliminating pests.

Contrary to scientists' loss of agency, in the foreign film dubbing arena, for example, filmmakers and dubbing actors in fact had ample agency to exercise their artistic judgement while operating under clear government directives. In the next essay by Nan Hu, "Familiar Strangers: Images and Voices of Soviet Allies in Dubbed Films in 1950s China," not only did filmmakers' and dubbing artists' agency remain fully intact, the self-other dynamics, the Cold War "us vs them" opposition, also played out quite differently than what the previous two essays have demonstrated. Tracing back to the historical moment when the PRC was founded in 1949, Chinese people's collective memory of and sentiment toward Russian aggression on the mainland was still fresh in their minds. How would the new government alter this mindset in the early years of the Cold War era when the PRC's alliance with the Soviet Union was crucial? Dubbing imported Soviet films was one way. The objective was to produce an image of the Soviet Big Brother as relatable, inspiring, and most importantly, familiar. Chinese filmmakers and dubbing actors derived their agency in speaking for the foreign other through such works as translating and modifying foreign materials to adjust to Chinese cultural norms, replacing Soviet filmic aesthetics with Chinese ones, and applying Chinese voicing techniques in dubbing. The outcome was a foreign film filled with non-Chinese looking actors and actresses speaking in familiar Chinese tongues.

The endeavour to create for the Chinese viewers a sense of familiarity towards the foreign other was not entirely successful. Hu argues that the image-voice split of the foreign characters in fact appeared quite unnatural and unbelievable to Chinese viewers. Furthermore, because their aesthetic demanded that they be faithful to the original, the dubbing actors worked hard to retain the authentic flavour of the foreign characters that they were portraying through voice performances. So the combined result, instead of creating a familiar other, was to make this foreign other even stranger. Although an unexpected product of the central government's strategy of bringing closer the Chinese and the Soviet peoples by way of dubbing Soviet films, these "familiar strangers" gradually were accepted by Chinese moviegoers who, as Hu concludes, actually found the foreignness and difference attractive precisely because these imported films provided a window for them to see the world outside.

Even though the majority of Chinese citizens could only imagine the world through foreign films, a privileged few could actually visit foreign countries. These were professional folk dancers. In the next essay, Emily Wilcox shows us some of socialist China's international cultural exchanges that were conducted through dance in venues such as World Youth Festivals, also known as World Festivals of Youth and Students (WFYS). "When Folk Dance Was Radical: Cold War Yangge, World Youth Festivals, and Overseas Chinese Leftist Culture in the 1950s and 1960s" challenges the existing notion that Mao's China was isolated from any cultural contact with other nations. Wilcox contends that the northern rural folk yangge 秩歌 dance, favoured by the Chinese Communist Party since the late 1930s, continued its popularity into the PRC era. Now with added dance choreographies drawn from folk performances of the southern regions, yangge dance, later renamed "Han folk dance" (Hanzu minjian wu 漢族民間舞), emerged not only as a symbol of ethnic and cultural unity achieved by the PRC, but also came to represent international socialism, or Cold War socialism, as Wilcox terms it. The yangge dance was widely performed in the Communist bloc, and its choreographies were adopted in Eastern Europe and the USSR. What is more interesting about the yangge phenomenon is that it also became popular in diasporic Chinese communities in Hong Kong, Singapore, Malaysia, and US cities such as San Francisco.

The Cold War geopolitics in this picture of socialist folk dance being permitted in the Capitalist bloc among the Chinese diaspora has a historical origin predating 1949. Wilcox points out that China's leftist performing arts such as yangge dance had already been introduced and circulated in Hong Kong and Southeast Asia during the 1940s. As traditional folk art, yangge dance was embraced by the Chinese diaspora even in the post-WWII Cold War era, when such folk dance was endowed with a heavy socialistcommunist political meaning. The Chinese diaspora's relationship with their homeland, now a communist regime, is complex. On the one hand, they remained emotionally attached to the Chinese mainland, while on the other hand, they now resided in the oppositional Capitalist bloc. Through performing yangge dance, members of the Chinese diasporic community were able to express their nostalgia for the homeland or could use the dance form to present their different political views.

Analysing the folk dance diplomacy of the Cold War reveals more than just the binary aspect of the two political and economic systems of communism and capitalism. The universality of folk art is challenged in the instance of yangge dance, as Wilcox demonstrates. In the next essay, another form of dance, ballet, is a catalyst to unravelling the entanglement of intercultural exchanges as well as the intertextual connectivity of propagandic productions during the later years of the Cold War in the 1970s. "Les Chinois à Paris: The Red Detachment of Women and French Maoism in the Mid-1970s" by Nan Ma delineates this dialogic complexity as found in the Chinese revolutionary ballet The Red Detachment of Women (1964) and the French satirical film Les Chinois à Paris (The Chinese in Paris, 1974). Arguing that The Red Detachment of Women was more than just a Cultural Revolution-style ideological project whose significance was confined to the national borders of the PRC, Ma contends that this model ballet can be seen as a site in which Cold War international cultural politics played out. The Chinese creation of The Red Detachment of Women was stimulated by the 
Soviet Union's ballets. Thanks to President Nixon's historical visit to China in 1972, during which the ballet was performed for the American Presidential couple and their viewing was televised and broadcasted worldwide, The Red Detachment of Women soon caught international attention and inspired similar productions in other countries.

To demonstrate socialist Chinese ballet's cultural influence beyond Chinese borders, Ma analyses the intertextual connectivity between the ballet The Red Detachment of Women and the French film Les Chinois à Paris. Through her comparative analysis of the ballet and the film, Ma reveals that the elite French Maoists, especially those on the editorial board of the highly influential theoretical journal Tel Quel such as Julia Kristeva and Roland Barthes, in fact carried with them and manifested in their writings an Orientalist view of their Chinese "other" - asexual and placid, and thereby "pre-symbolic" (see Ma's article in this issue). This leftist theoretical imagination of socialist China was satirised by the film through parodying The Red Detachment of Women in the film's retelling of the French opera Carmen. The comic and satirical representation of Carmen, as Ma contends, is itself a critique of the French Maoists' fascination with Mao's Cultural Revolution, on the one hand. The film's presentation of Carmen, on the other hand, also reveals how the divisive Cold War ideologies in the 1950s and part of the 1960s gradually lost their distinction as left-leaning elite intellectuals in the Capitalist bloc began to find in Maoism, based on their understanding of it, a path to a utopian and anarchistic society where there exists no hierarchy of governing power, no distinction between politics and art, and no economic stratification of people. An unexpected by-product of intercultural exchanges and influences, as generated by The Red Detachment of Women, is what Ma articulates, "the imagined Maoist 'other' is not fundamentally different from the French bourgeois 'self'" (see Ma's article in this issue).

The Cold War is indeed a war of perception and optics, as the five essays in this special issue have laid bare. This war finds its best and most effective weaponry in the soft power of culture and scientific and technological hardware. The cultural Cold War has attracted much scholarly attention in recent years and has opened up a new investigative space for us to better understand the Cold War itself. It is the aim of this special issue to focus our attention on East Asia, and particularly on the role socialist China played during those contentious years.

I Lingchei Letty Chen is Associate Professor of Modern Chinese Literature in the Department of East Asian Languages and Cultures, Washington University in St. Louis, One Brookings Drive, St. Louis, Missouri 63130, USA (llchen@wustl.edu).

I This special issue originates from an international conference held on 25-26 March 2017 at Washington University in St. Louis. The conference was funded by a grant from the Ministry of Education of the Republic of China in Taiwan, and supported by Capital Normal University in Beijing (People's Republic of China) and the Department of East Asian Languages and Cultures of Washington University in St. Louis, Missouri (United States).

\section{References}

CHEN, Jian. 2001. Mao's China and the Cold War. Chapel Hill and London: University of North Carolina Press.

CHOU, Grace Ai-Ling. 2011. Confucianism, Colonialism, and the Cold War. Leiden: Brill.

HAJIMU, Masuda. 2015. Cold War Crucible. The Korean Conflict and the Postwar World. Cambridge: Harvard University Press.

KWON, Heonik. 2010. The Other Cold War. New York: Columbia University Press.

LIU, Petrus. 2019. "Cold War Aesthetics in East Asia." In Mayumo Inoue and Steve Choe (eds.), Beyond Imperial Aesthetics: Theories of Art and Politics in East Asia. Hong Kong: Hong Kong University Press. 52-76.

VEGSO, Roland. 2013. The Naked Communist: Cold War Modernism and the Politics of Popular Culture. New York: Fordham University Press.

WALKER, Martin. 1993. The Cold War: A History. New York: Henry Holt and Company.

WANG, Ban. 2002. "The Cold War, Imperial Aesthetics, and Area Studies." Social Text 20(3): 45-65.

WANG, Xiaojue. 2013. Modernity with a Cold War Face. Reimagining the Nation in Chinese Literature Across the 1949 Divide. Cambridge: Harvard University Asia Center.

WILCOX, Emily. 2018. Revolutionary Bodies. Chinese Dance and the Socialist Legacy. Berkeley: University of California Press. 